\title{
Key Issues Related to the Construction of A Nuclear Power Plant in Poland
}

\author{
Sławomir Jankiewicz \\ Faculty of Finance and Banking \\ WSB w Poznaniu \\ Poznan, Poland \\ e-mail: slawomir.jankiewicz@wsb.poznan.pl
}

\author{
Dominika Mierzwa \\ Faculty of Management \\ WSOWL im. Tadeusza Kościuszki \\ Wroclaw, Poland \\ e-mail: d.mierzwa1@wso.wroc.pl
}

\begin{abstract}
Economic growth requires an increase in Poland, the supply of electricity. Therefore it was decided to build nuclear power plants. The paper synthetically presents the concept of building a nuclear power plant proposed by the government and implemented by PGE with a foreign partner.
\end{abstract}

Keywords-economic growt; nuclear power plant

\section{INTRODUCTION}

Poland, like any country that wishes to achieve a high rate of economic growth. The current downturn in the world meant that become a priority for action to mitigate the effects of the crisis. According to the basics of the theory of the business cycle, we can accept the hypothesis that within 1-2 years there is a change cycle and return to growth. That is why today we should reflect on the barriers to its implementation. One of the key may be the energy market. Lack of competition among electricity suppliers in Poland and a very large share of trade unions in the management of energy, which affects the generation of unjustified costs and impede the introduction of mechanisms to influence the pro of efficiency at a high price for this product. Moreover, the problem is to ensure adequate supply, which is related to the need to increase capacity. The increase in electricity demand in the coming years may lead to imbalance of energy security and the deficit in energy supply will lead to a substantial in some countries, temporary black-out.

Polish energy sector is related to traditionally generation sources, ie coal and lignite. Renewable sources of generation are small part. For this reason, the great hopes among others of nuclear energy, which, according to government plans to constitute a significant source of electricity production. Therefore, the announcement by the Prime Minister's ambitious plan to start the first nuclear power plant in 2020 . But for these plans could be realized, it is necessary first to create a sound legal basis.

The article analyzes the basic legislation concerning the electricity market in Poland and presents synthetically the problems associated with traditional energy production and use of nuclear energy.

\section{Basic Legal Regulations AfFecting the ELECTRICITY MARKET}

Legislation affecting directly and indirectly on the energy sector in Poland are introduced both by international organizations (eg European Union) and national institutions.
The most important and also most difficult to implement in a country act in the coming years is the EP adopted Directive 2005/32/EC, which implies a reduction of 2020 greenhouse gas emissions by $20 \%$, increase energy efficiency by $20 \%$ and increased use of renewable energy here $20 \%$. Another regulation that applies to the so-called. Kyoto Protocol is Cogeneration Directive 2004/8/EC of the European Parliament and the Council of 11 February 2004, envisages the development of cogeneration, which aims to contribute to improving security of energy supply. Another important factor, which in recent years, dramatically affected the situation of the companies in the sector is Directive 2003/54/EC of 26 June 2003, and Article. 9d Law of 10 April 1997 Energy Law for the separation of distribution activities from energy trading activities [3]. This regulation would affect the full release of the market from 1 July 2007 and the launch of competition in the sector. Moving away from the problems of economic aspects of changing energy suppliers for compliance with this directive must be noted that the mere adaptation of organizational and legal entities of distribution was one of the major problems in recent years in Poland. These problems stemmed from the following factors:

- The absence of clear ownership of the decision model, the implementation of organizational changes on the operation of the Distribution System Operator,

- Social difficulties in the implementation of any model to adapt to the requirements of the Directive,

- Radical personnel changes in key positions in the energy sector companies,

- Significant impact of these changes on the realm of organizational entities[4].

- Given the importance of strategic market for generation and transmission of electricity is heavily regulated and at national level and throughout the Community. In the case of the European Union, important provisions include:

- Directive 2003/87/EC of the European Parliament and the Council of 13 October 2003 establishing a scheme for trading greenhouse gas emissions within the Community and amending Council Directive 96/61/EC,

- Directive 2004/101/EC of the European Parliament and the Council of 27 October 2004 amending Directive 2003/87/EC establishing a scheme for trading greenhouse gas emissions in the Community, 
including the project mechanisms of the Kyoto Protocol,

- European Parliament and Council 2009/29/EC of 23 April 2009 amending Directive 2003/87/EC to improve and extend the EU trading scheme for greenhouse gas emissions,

- Council Directive 92/75/EEC of 22 September 1992 on the indication by labeling and standard product information of the consumption of energy and other resources by household appliances,

- Directive 2002/91/EC of the European Parliament and the Council of 16 December 2002 on the energy performance of buildings,

- Directive 2006/32/EC of the European Parliament and the Council of 5 April 2006 on energy end-use efficiency and energy services and repealing Council Directive 93/76/EEC,

- Directive 2005/89/EC of the European Parliament and the Council of 18 January 2006 concerning measures to safeguard security of electricity supply and infrastructure investment,

- Directive 2005/32/EC of the European Parliament and the Council of 6 July 2005 laying down general rules for setting ecodesign requirements for energyusing products and amending Council Directive 92/42/EEC and Directives of the European Parliament and Council 96/57/EC and 2000/55/EC,

- European Parliament and Council 2008/92/WE of 22 October 2008 concerning a Community procedure to improve the transparency of prices of gas and electricity to industrial end-users (recast),

- European Parliament and Council 2009/28/EC of 23 April 2009 on the promotion of the use of renewable energy and amending and repealing following Directives 2001/77/EC and 2003/30/EC,

- European Parliament and Council 2009/30/WE of 23 April 2009 amending Directive 98/70/EC relating to the specification of petrol and diesel fuels and introducing a mechanism to monitor and reduce greenhouse gas emissions and amending Council Directive 1999/32 / EC relating to the specification of fuel used by inland waterway vessels and repealing Directive 93/12/EEC,

- European Parliament and Council 2009/31/EC of 23 April 2009 on the geological storage of carbon dioxide and amending Council Directive 85/337/EEC, Euratom, the European Parliament and Council 2000/60/EC, 2001/80 / EC, 2004/35/EC, 2006/12/EC, 2008/1/EC and Regulation (EC) No 1013/2006,

- Regulation (EC) No 1228/2003 of the European Parliament and the Council of 26 June 2003 on conditions for access to the network for cross-border exchanges in electricity,

- Commission Regulation (EC) No 994/2008 of 8 October 2008 in a standardized and secured system of registries pursuant to Directive 2003/87/EC of the European Parliament and Council and Decision No
280/2004/EC of the European Parliament and Council,

- Regulation of the European Parliament and Council Regulation (EC) No 443/2009 of 23 April 2009 laying down emission standards for new passenger cars as part of an integrated Community approach to reduce $\mathrm{CO} 2$ emissions from light commercial vehicles,

- Regulation of the European Parliament and Council Regulation (EC) No 219/2009 of 11 March 2009 adapting to Council Decision 1999/468/EC of instruments subject to the procedure referred to in Article. 251 of the Treaty, the regulatory procedure with scrutiny - Part Two,

- Commission Decision of 18 July 2007 establishing guidelines for the monitoring and reporting of greenhouse gas emissions pursuant to Directive 2003/87/EC of the European Parliament and Council,

- Decision of the European Parliament and Council 2009/406/WE of 23 April 2009 on the efforts undertaken by Member States to reduce greenhouse gas emissions in order to implement the 2020 Community's commitments to reduce greenhouse gas emissions.

The amount of regulation, on the other hand, addressing the EU's electricity market integration makes it necessary to coordinate policies affecting the sector in all countries. Therefore, currently at the European Parliament and Council are working towards the establishment of the Agency for the Cooperation of Energy Regulators.

For national documents relevant to the energy sector are primarily: Polish Energy Policy until 2030, the Energy Law Act, which as of the consolidated text on 21 May 2009, the Legal Office has developed the Energy Regulatory Office and the Ministry of the Economy of 2 July 2007 . on detailed rules for the formulation and the calculation of tariffs and settlements in the electricity and the Minister of Economy of 4 May 2007 on detailed conditions for the functioning of the electricity system.

\section{EleCtricity GENERATION BASED ON TRAdITIONAL FUELS AND RENEWABLE SOURCES}

In Poland energy produced on traditional fuels - coal and lignite accounts for more than $90 \%$ of the total energy. However, this type of power will have a problem in the future. It is the fuel for which the number is steadily decreasing, and reach new layers of material requires considerable investment, which will entail an increase in prices. Already in 2009 compared to last year there was a significant increase in average prices. Although built in the country out of the new power units use modern high efficiency and low carbon technologies. However, all the time in the case of electricity generation using coal there is a problem with the issue of multiple pollutants in the environment. They concern not only carbon dioxide, but also many other components, such as sulfur and particulates. Trying to limit the amount of harmful substances passing into the environment (eg. capture dust, carbon capture and 
collect it into the ground) all the time, however, these amounts are significant. Adding fuel to this problem, the number has been steadily decreasing, we can conclude that the generation of electricity from conventional fuels will decline steadily. As an alternative, or at least be complementary to renewable energy sources, the use of national technical potential is estimated at about $14 \%$ of current primary energy consumption, while the current share of renewable energy in the fuel balance is about 4\% [5].

The most important renewable energy sources include energy:

- Water,

- Wind,

- Biomass,

- Geothermal energy.

Production of electricity from water, including geothermal energy in Poland will always constitute a small percentage. This is due to natural conditions and hydrographic enjoyed in our country. The second reason is the lack of effective energy management policy, system of watercourses (rivers, canals and lakes flow).

In Poland, currently operates six businesses that use geothermal heat, including the largest company PEC Podhale Geothermal Energy SA in Banska Niżna near Zakopane, where the geothermal heat output is about $40 \mathrm{MW}$. In other thermal power produced ranges from a dozen to a few MW. It is worth noting is still occurring in Poland irrational administrative and bureaucratic resistance to attempts to exploit this potentially significant energy source.

Burning biomass will remain the primary source of green energy, especially heat. Biomass is a renewable energy source, but in the Polish comes mainly from by-products of agriculture and forestry, hence it is energetically inefficient. Therefore put on the processing of compacted biomass pellets and briquettes, which contain traces of high energy substances, such as vegetable oils, which increases their calorific value and energy efficiency in the combustion process. In Poland, for energy purposes are currently being grown include:

- Willow (the most common energy crops in Poland),

- Virginia mallow,

- Giant miscanthus, sugar miscanthus,

- Spartina prairie.

In addition, for energy purposes are also cultivated cereals (eg oats) and other crops like sunflower and rape.

Energy crops are limited in terms of species selection. Act of April 16, 2004 on Nature Protection prohibits the natural environment and the movement in this environment, plants, animals or fungi alien species and their developmental forms [6], due to the increasing range of crops and monocultures in Poland spread of alien invasive plants.

Production and use of biofuels in Poland brings high hopes, but is still at a very low significance. Increased production will undoubtedly result in more professional activation of rural areas and reduction of hidden unemployment, as well as reduce the independence of the Polish market of suppliers of fuel oil and natural gas.
According to the information given in 2008 by the European Wind Energy Association (EWEA) 43 percent. newly installed capacity in the EU came from wind energy, surpassing the same technology using conventional energy sources (coal, gas and petroleum). Wind power has therefore become the leading technology of generating electricity. At the end of 2008 the total installed capacity of wind power in the EU was $64949 \mathrm{MW}$, which would give a year to produce 142 TWh of electricity and 4.2 percent cover. requirements of the European Union. In the case of Polish, according to the Energy Regulatory Office (ERO), at the end of 2008 the total installed capacity of 227 licensed wind energy amounted to $451.09 \mathrm{MW}$ ( $472 \mathrm{MW}$ by EA), and the production of $790.2 \mathrm{GWh}(494.2 \mathrm{GWh} 2007)$.

In 2008, investors have made the connection conditions for wind power plants with a capacity of about seven thousand. MW and expertise made for instance for a connection conditions on the capacity of about 49 thousand. MW. The real level of development of wind energy in Poland by 2020 is to install 1911 to 1914 thousand. MW and achieve the production of electricity from wind power at 1924 to 1931 TWh, which can cover about 12 percent. electricity demand in 2020 This assessment coincides with the analysis of ERO indicating that investors are interested in the building of 2030 wind turbines with a capacity of about 16 thousand. MW, nearly half of installed capacity currently in the Polish power system.

\section{Nuclear Power - the Prospect of DeVElopment IN POLAND}

Nuclear power is the youngest area of energy, it has been started in the fifties the twentieth century, dynamic development of nuclear energy took place in the sixties and seventies of last century. This development has been hindered in highly developed countries, after two major accidents (Three Mile in 1979 and Chernobyl in 1986). However, depletion of fossil resources and increasing their prices, reduce greenhouse gas emissions caused renewed interest in this type of methods of generating electricity. In 2006 it was operating 435 nuclear reactors with a capacity of $367 \mathrm{GW}$. The highest share of nuclear energy in electricity production in 2005 have been: France - 78\%, Lithuania $70 \%$, Belgium and Slovakia - 56\%, Ukraine - 49\%, and Sweden $-47 \%$.

Currently in Poland are ongoing discussions about the need to build a nuclear power plant. At the beginning of the year 2009 (January 13), the government adopted a resolution on the development of this energy. Created an implementation plan for two nuclear power plants, which, according to the objectives is to pursue the Polish Energy Group. Account is taken of nine investment location. The plans assume that 2020 will be launched at least one such plant. Despite ambitious plans to create a nuclear power plant within a given period is not realistic. This is due to technical problems, financial and organizational.

The first major barrier to enact regulations on power plant construction and operation of this type. It was only this year established a representative government that will deal with nuclear power. The currently valid law - Atomic Law, 
governs only the operation of research reactors. Does not regulate the power requirements of localization, technical and organizational requirements that must be met during construction and operation of nuclear power. Construction, commissioning and operation of such plants will be connected with many areas of regulation, standardizated out for several types of legislation, including the right to atomic energy law, construction law, environmental law. It is therefore necessary to adapt the law in many respects. Work all the way legislative and takes time. Specific, that different political parties and opinion leaders will have their proposals for solutions that will want to push. The discussion will be probably difficult and long, and the formation of legal standards related to nuclear power is just the beginning through to construction.

Next barrier is related to the agreement of local community and environmental organizations for a specific location. The majority of Poles agree with the need for the construction of nuclear power, but do not want this to be in the immediate vicinity thereof. The public consultation will ensure a long and stormy. Suffice it to recall the problem of building the road through the valley "Rozpudy" whether the construction of the power grid in the. Marketing efforts to run the blockade and the courts allowed the organizations to effectively stop environmental works in either case. Similar situation can be expected when the construction of power plants. Obtaining permits can take several years so. The choice of technology partner for the project and the method and sources of funding also will require time. Like the construction process.

Development of nuclear energy in Poland will not be possible without intensive international cooperation. It is necessary for many reasons, including:

- The choice of safe technologies,

- Raise funds for investment,

- The scientific development in the field of nuclear,

- Acquisition of knowledge, such as to overcome prejudices and fears, organize the construction and operation.

It must be concluded that the first nuclear power plant in Poland still wait. You can not because in ten years to make a fundamental breakthrough in this field. Evidence of this building process in countries which already have long since this type of power. For example, in Finland is currently building another nuclear plant. In May 1998, preparatory work began, which lasted until 2002. Construction began only four years after the start and planned to end it was not until 2012-2013. The process of investment will continue, under favorable circumstances, until 14-15 years. In most cases this is the time that elapses from the time to take action on the construction of a nuclear power plant until its launch. Adopted ten years, which is to be built in Poland a nuclear power seems to be a very short period. More likely is the emergence of the first nuclear power plant around 2025. Should also be noted that they are the first plants with relatively small power.

\section{CONCLUSION}

In Poland, high economic growth is necessary to ensure an adequate supply of electricity. Unfortunately, estimates show that as early as 2013, may need to import it. Limitations and not permit the transfer of energy from abroad in the required number, which can cause inhibition of growth. So it is necessary to develop national capacity. Nuclear power in the case of our country in the near term, only plans. The first plants of this type will provide electricity until about 2025. There will also be important from the viewpoint of supply, since the first units will have capacity of about $1000 \mathrm{MW}$. A chance to meet growing demand for electricity is the development of traditional forms of generation and renewable sources. It is necessary above all to promote the construction of wind power, and based on the so-called. primary fuel. This will allow the donation of new capacity on average, about $1000 \mathrm{MW}$ per annum and will meet growing demand for electricity

\section{REFERENCES}

[1] S. Jankiewicz: Deficyt budżetowy jako bariera przemian strukturalnych w Polsce, in: Przemiany strukturalne polskiej gospodarki wobec wyzwań integracyjnych z Unią Europejską, ed. Z. Mikołajewicz, Uniwersytet Opolski, Opole 2004, pp. 301-313,

[2] S. Jankiewicz, Polityka gospodarcza wobec koncentracji i niestabilności systemu rynkowego, Polityka Gospodarcza, Vol. 11 (2005), pp. $257-269$.

[3] P. Białowąs, Model zarządzania strategicznego i operacyjnego - w kierunku wzrostu efektywności działania przedsiębiorstwa, Zarządzanie jakością, Vol. 2 (2007).

[4] G. Jezierski, Energia jądrowa wczoraj i dziś, WNT, Warszawa 2005.

[5] W. Kamrat, A. Augusiak, Wpływ konkurencji na rynki paliw i energii, w: Zagadnienia surowców energetycznych i energii w gospodarce rynkowej, Zakopane, 8 listopad 2006.

[6] Dziennik Ustaw z 2004 roku Nr 92, poz. 880 z późn zm. 